\title{
Koreibacter algae gen. nov., sp. nov., isolated from seaweed
}

\author{
Dong Wan Lee and Soon Dong Lee
}

Correspondence

Soon Dong Lee

sdlee@jejunu.ac.kr
Department of Science Education, Jeju National University, Jeju 690-756, Republic of Korea
The suborder Micrococcineae (Stackebrandt et al., 1997) is one of the largest and most diverse taxa in the class Actinobacteria and originally contained nine families: Micrococcaceae, Brevibacteriaceae, Cellulomonadaceae, Dermabacteraceae, Dermatophilaceae, Intrasporangiaceae, Jonesiaceae, Microbacteriaceae and Promicromonosporaceae. Five novel families have been subsequently added to the suborder on the basis of phylogenetic analysis: Bogoriellaceae, Dermacoccaceae, Rarobacteraceae, Sanguibacteraceae (Stackebrandt \& Schumann, 2000) and Yaniellaceae (Li et al., 2008). To include these novel taxa, the descriptions of these families were recently emended on the basis of phylogenetic analyses and the signature patterns of their 16S rRNA gene sequences, and, based on this revision, the new family Beutenbergiaceae was created in the suborder Micrococcineae (Zhi et al., 2009). This paper describes the classification of a Micrococcineae strain that was isolated from seaweed.

Strain DSW $-2^{\mathrm{T}}$ was isolated from a sample of an unknown seaweed collected around Mara Island in Jeju, Republic of Korea. The seaweed was directly spread onto SC-SW agar $\left(1 \%\right.$ soluble starch, $0.03 \%$ casein, $0.2 \% \mathrm{KNO}_{3}$, $0.2 \% \mathrm{NaCl}, \quad 0.2 \% \quad \mathrm{KH}_{2} \mathrm{PO}_{4}, \quad 0.002 \% \mathrm{CaCO}_{3}, 0.005 \%$ $\mathrm{MgSO}_{4} .7 \mathrm{H}_{2} \mathrm{O}, 0.001 \% \mathrm{FeSO}_{4} .7 \mathrm{H}_{2} \mathrm{O}, 1.8 \%$ agar; $60 \%$ natural seawater and $40 \%$ distilled water) and the plate was incubated at $30{ }^{\circ} \mathrm{C}$ for 2 weeks. The isolate was maintained

The GenBank/EMBL/DDBJ accession number for the $16 \mathrm{~S}$ rRNA gene sequence of strain DSW-2 ${ }^{\top}$ is FM995611.

Details of additional sequences used in the construction of Fig. 2 and $16 \mathrm{~S}$ rRNA gene sequence similarities are available as supplementary material with the online version of this paper. on marine agar (MA; Difco) and in $20 \%(\mathrm{v} / \mathrm{v})$ glycerol suspensions containing $60 \%$ natural seawater and $20 \%$ distilled water at $-20{ }^{\circ} \mathrm{C}$ and $-80{ }^{\circ} \mathrm{C}$, respectively.

Cell morphology and motility were observed by using phase-contrast and transmission electron microscopy, with cells grown on $\mathrm{MA}$ at $30{ }^{\circ} \mathrm{C}$ for 5 days. Colony characteristics were observed on MA at $30{ }^{\circ} \mathrm{C}$ for 5 days. Conditions for growth were examined on MA at 4, 10, 20, 25, 30, 37, 40 and $45{ }^{\circ} \mathrm{C}$ and $\mathrm{pH} 3.5,4.1-12.1$ (in intervals of one $\mathrm{pH}$ unit), 13.0 and 14.0 and on tryptic soy agar (TSA; Difco) supplemented with $1-12 \%(\mathrm{w} / \mathrm{v}) \mathrm{NaCl}$ (in intervals of $1 \%)$. Gram stain, oxidase and catalase activities and degradation and utilization of carbohydrates were tested by using previously described methods (Lee \& Lee, 2008). Enzyme activities were determined by using the API ZYM kit (bioMérieux), according to the manufacturer's directions.

Cells of strain DSW $-2^{\mathrm{T}}$ were aerobic, Gram-positive, nonmotile rods $(0.3-0.5 \times 1.5-2.3 \mu \mathrm{m})$ (Fig. 1). Colonies of the cells were light yellow, circular and convex with entire margins, approximately $0.5-0.8 \mathrm{~mm}$ in diameter after incubation on MA at $30{ }^{\circ} \mathrm{C}$ for 5 days. Physiological and biochemical properties are given in the genus and species descriptions.

Genomic DNA was isolated according to the method of Hopwood et al. (1985). Amplification of the 16S rRNA gene and sequencing were performed as described previously (Lee \& Lee, 2008). The partial 16 S rRNA gene sequence of strain DSW $-2^{\mathrm{T}}$ determined in this study (1401 nt) was subjected to a preliminary BLAST search against 


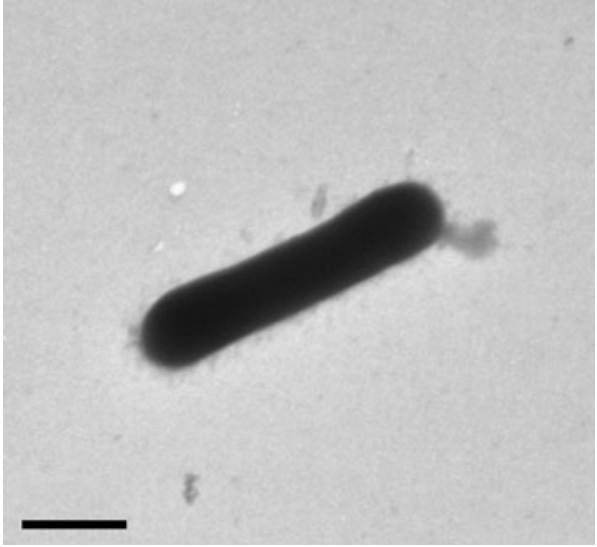

Fig. 1. Transmission electron micrograph of a cell of strain DSW-2 grown on MA at $30{ }^{\circ} \mathrm{C}$ for 5 days. Bar, $0.5 \mu \mathrm{m}$.

GenBank entries, which showed maximum similarities of less than $96 \%$ to members of the families Cellulomonadaceae, Sanguibacteraceae and Promicromonosporaceae in the suborder Micrococcineae. The CLUSTAL X program (Thompson et al., 1997) was used to create a multiple alignment of the sequences of strain DSW $-2^{\mathrm{T}}$ and representatives of the suborder Micrococcineae. The alignment was optimized manually according to the secondary structure of the Escherichia coli 16S rRNA molecule (Brosius et al., 1978). A total of 1201 unambiguous nucleotides present in all strains (E. coli positions 45 and 1464) was used for tree construction. Phylogenetic analyses were performed with several treeing algorithms contained in the PHYLIP software package (Felsenstein, 1993). An evolutionary distance matrix was calculated using the model of Jukes \& Cantor (1969) and a phylogenetic tree was constructed with the neighbour-joining method (Saitou \& Nei, 1987). Bootstrap analysis (Felsenstein, 1985) was performed with 1000 resamplings.

The $16 \mathrm{~S}$ rRNA gene sequence tree (Fig. 2 and Supplementary Table S1, available in IJSEM Online) shows that strain DSW $-2^{\mathrm{T}}$ belongs to the suborder Micrococcineae and forms a lineage distinct from those of several Micrococcineae representatives. 16S rRNA gene sequence similarity values between strain DSW- ${ }^{\mathrm{T}}$ and representatives of Micrococcineae genera were as follows: in the family Cellulomonadaceae, 96.1-96.4\% (Oerskovia), 93.8-95.6\% (Cellulomonas) and $94.8 \%$ (Actinotalea); in the family Sanguibacteraceae, 95.3-96.1\% (Sanguibacter); in the family Promicromonosporaceae, 95.3-96.1\% (Cellulosimicrobium), 94.7-95.3\% (Isoptericola) and 94.2-95.8\% (Promicromonospora); and in the family Beutenbergiaceae, $95.2 \%$ (Beutenbergia). Levels of 16S rRNA gene sequence similarity between the novel strain and other representatives of this suborder were $94.6 \%$ or less (Supplementary Table S2, available in IJSEM Online). In other analyses with a total of $1339 \mathrm{nt}$ present in all strains, 16S rRNA gene sequence similarity values between strain DSW $-2^{\mathrm{T}}$ and representatives of this suborder were slightly lower $(0.4 \pm 0.3 \%)$ than those described above (data not shown).

The amino acid composition of the cell-wall peptidoglycan was determined by reversed-phase HPLC (Waters 2690) as described previously (Lee, 2007). Purified cell-wall material was prepared according to the method of Hancock (1994). Cell-wall sugars were analysed by GC as described by Saddler et al. (1991). Menaquinones were analysed by HPLC as described by Kroppenstedt (1985). Polar lipids were determined by TLC as described by Minnikin et al. (1975). Cellular fatty acids of strain DSW-2 ${ }^{\mathrm{T}}$ were determined by using cells grown on TSA for 3 days at $30{ }^{\circ} \mathrm{C}$ and analysis of the methyl esters was performed according to the instructions of the Microbial Identification System (version 6; MIDI). The G + C content of the DNA was determined by HPLC according to Mesbah et al. (1989).

The purified cell wall of strain DSW $-2^{\mathrm{T}}$ contained lysine as the diagnostic diamino acid. The molar ratio of Ala/Ser/ Glu/Lys was estimated to be $1.5: 0.6: 1.0: 1.0$. Asp and Gly were not detected. These results suggested that the structure of the linkage is Lys-Ser and that the peptidoglycan type is A3 $\alpha$ (Schleifer \& Kandler, 1972). The cell-wall sugar was galactose. The predominant menaquinone was MK-9 $\left(\mathrm{H}_{4}\right)$. The polar lipids were phosphatidylglycerol and phosphatidylinositol. The cellular fatty acid profile of strain DSW $-2^{\mathrm{T}}$ contained ai- $\mathrm{C}_{15: 0}(80.7 \%)$, ai- $\mathrm{C}_{17: 0}(3.9 \%)$, $\mathrm{C}_{16: 0}(3.5 \%), \quad \mathrm{i}-\mathrm{C}_{14: 0}(2.5 \%), \quad \mathrm{i}-\mathrm{C}_{16: 0}(2.1 \%), \mathrm{C}_{18: 0}$ $(1.8 \%), \mathrm{C}_{14: 0}(1.1 \%)$ and $\mathrm{i}-\mathrm{C}_{15: 0}(1.1 \%)$. The $\mathrm{G}+\mathrm{C}$ content of the DNA was $68.3 \mathrm{~mol} \%$.

The 16S rRNA gene sequence analysis clearly showed that strain DSW $-2^{\mathrm{T}}$ belongs to the suborder Micrococcineae. This is also supported by the possession of $16 \mathrm{~S}$ rRNA gene sequence signature nucleotides of the Micrococcineae lineage (Zhi et al., 2009). However, the novel strain can be readily differentiated from phylogenetically closely related genera of this suborder by its chemotaxonomic properties and, in particular, the combination of the diamino acid type and the composition of interpeptide bridges in the cell-wall peptidoglycan (Table 1). For example, the genera Cellulosimicrobium, Oerskovia and Sanguibacter contain lysine as the diamino acid in the cellwall peptidoglycan and have MK-9 $\left(\mathrm{H}_{4}\right)$ as the major menaquinone, as does strain DSW-2 ${ }^{\mathrm{T}}$, but they clearly differ from strain DSW-2 ${ }^{\mathrm{T}}$ in the composition of the interpeptide bridges in the cell-wall peptidoglycan, the major cellular fatty acids and requirement for oxygen for growth.

On the basis of its phenotypic features and distinct phylogenetic position, strain DSW $-2^{\mathrm{T}}$ is considered to be well separated from all genera of the suborder Micrococcineae. The name Koreibacter algae gen. nov., sp. nov. is proposed. 


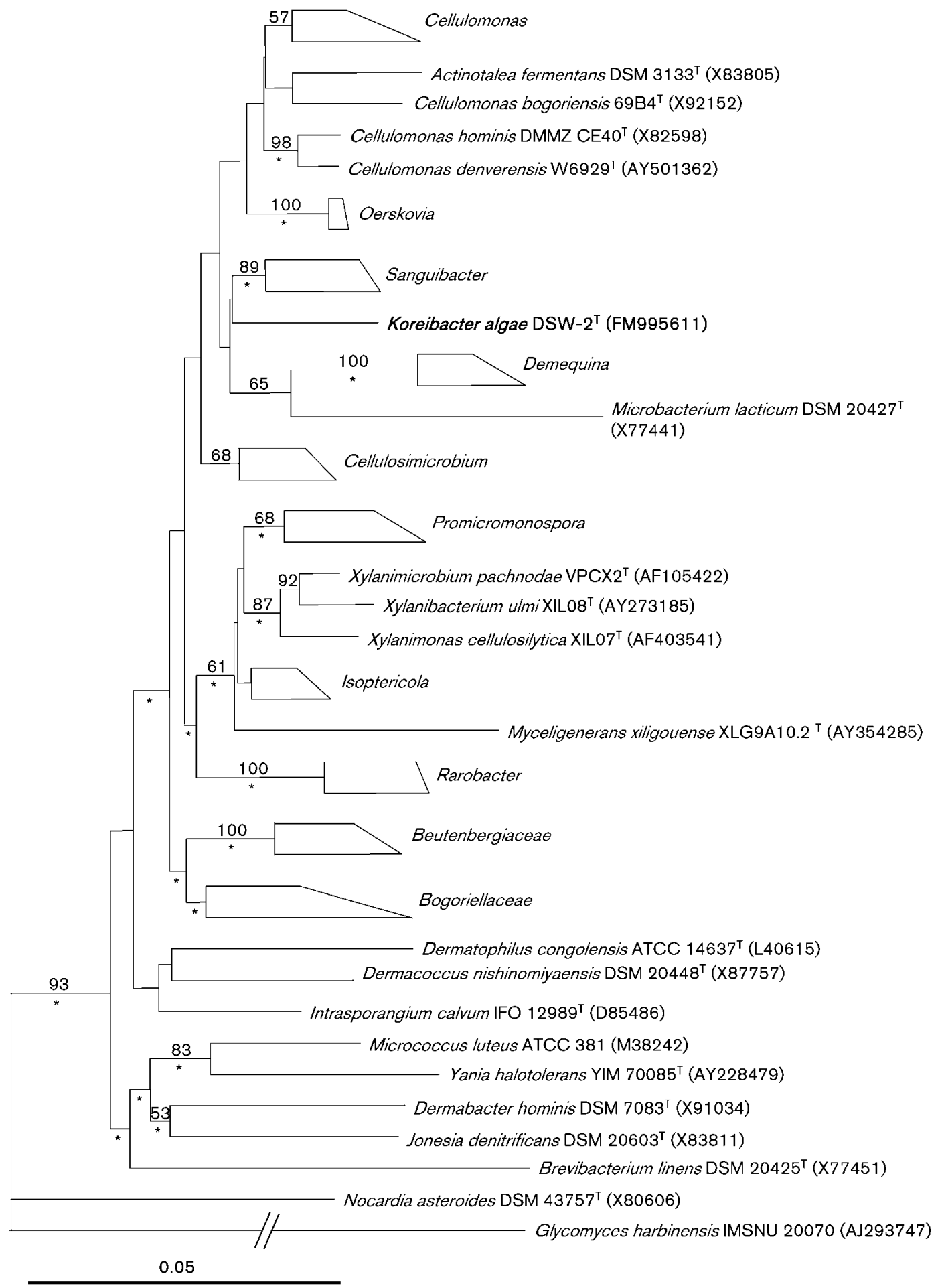

Fig. 2. Phylogenetic tree based on $16 \mathrm{~S}$ rRNA gene sequences showing the position of strain $D S W-2^{\top}$ amongst representatives of the suborder Micrococcineae, constructed from an evolutionary distance matrix with the neighbour-joining method. The taxa and sequences used for the genus or family groups and not shown are detailed in Supplementary Table S1. Bootstrap values $(>50 \%)$ based on 1000 resamplings are shown at branch nodes. Asterisks indicate that the corresponding nodes were also recovered in maximum-likelihood and maximum-parsimony trees. Glycomyces harbinensis IMSNU 20070 was used as an outgroup. Bar, 0.05 substitutions per nucleotide position. 
Table 1. Differential characteristics of strain $D S W-2^{\top}$ from the phylogenetically closely related genera of the suborder Micrococcineae

Taxa: 1, Koreibacter algae gen. nov., sp. nov., DSW-2 ${ }^{\mathrm{T}}$; 2, Actinotalea (Bagnara et al., 1985; Yi et al., 2007); 3, Beutenbergia (Groth et al., 1999); 4, Cellulosimicrobium (Schumann et al., 2001; Brown et al., 2006; Yoon et al., 2007); 5, Cellulomonas (An et al., 2005; Brown et al., 2005; Elberson et al., 2000; Jones et al., 2005; Rivas et al., 2004); 6, Isoptericola (Stackebrandt et al., 2004; Zhang et al., 2005; Groth et al., 2005); 7, Oerskovia (Stackebrandt et al., 2002); 8, Promicromonospora (Alonso-Vega et al., 2008; Busse et al., 2003; Kalakoutskii et al., 1989; Takahashi et al., 1987; Jiang et al., 2009); 9, Sanguibacter (Huang et al., 2005; Hong et al., 2008). A, Aerobic; F, facultatively anaerobic.

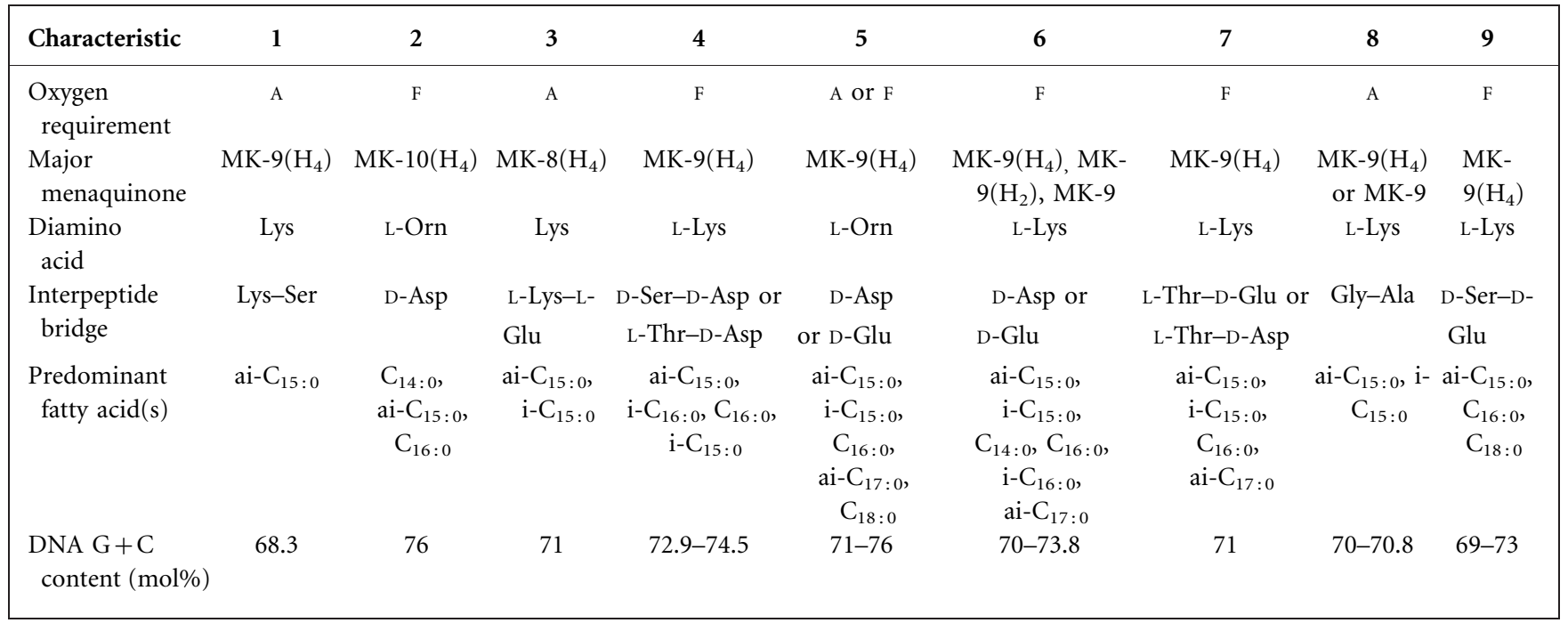

\section{Description of Koreibacter gen. nov.}

Koreibacter (Ko.re.i.bac'ter. N.L. n. Korea, Korea; N.L. masc. n. bacter rod; N.L. masc. n. Koreibacter a Korean rod, a rod isolated from Korea, referring to the site from which the type strain of the type species was isolated).

Cells are Gram-positive, aerobic, oxidase-negative, catalase-positive, non-motile rods $(0.3-0.5 \times 1.5-2.3 \mu \mathrm{m})$. The peptidoglycan type is A $3 \alpha$ with Lys-Ser as the interpeptide bridge. The whole-cell sugar is galactose. The major menaquinone is MK-9 $\left(\mathrm{H}_{4}\right)$. The predominant fatty acid is ai- $\mathrm{C}_{15: 0}$. The polar lipids are phosphatidylglycerol and phosphatidylinositol. The DNA $\mathrm{G}+\mathrm{C}$ content is $68.3 \mathrm{~mol} \%$. Phylogenetically, the genus is a member of the suborder Micrococcineae, order Actinomycetales. The type species is Koreibacter algae.

\section{Description of Koreibacter algae sp. nov.}

Koreibacter algae (al'gae. L. gen. n. algae of alga, seaweed).

The morphological and chemotaxonomic characteristics are the same as those given in the genus description. Colonies are light yellow, circular, convex with entire margins and approximately $0.5-0.8 \mathrm{~mm}$ in diameter after incubation on $\mathrm{MA}$ at $30{ }^{\circ} \mathrm{C}$ for 5 days. Growth occurs at $10-37{ }^{\circ} \mathrm{C}$ (optimum $25-30{ }^{\circ} \mathrm{C}$ ) and at $\mathrm{pH} 4.1-12.1$ (optimum $\mathrm{pH} 7.1$ ), but not at $\mathrm{pH} 3.5$ and 13.0, and with $0-10 \% \mathrm{NaCl}$ (optimum 1-4\%). DNA is degraded, but casein, cellulose, chitin, elastin, hypoxanthine, starch, Ltyrosine and xanthine are not. Enzyme tests with the API ZYM system are positive for $\alpha$-glucosidase and $N$-acetyl- $\beta$ - glucosaminidase, weakly positive for esterase (C4) and esterase lipase (C8) and negative for alkaline phosphatase, lipase (C14), leucine arylamidase, valine arylamidase, cystine arylamidase, trypsin, $\alpha$-chymotrypsin, acid phosphatase, naphthol-AS-BI-phosphohydrolase, $\alpha$-galactosidase, $\beta$-galactosidase, $\beta$-glucuronidase, $\beta$-glucosidase, $\alpha$-mannosidase and $\alpha$-fucosidase. Acid is produced from maltose, L-rhamnose, trehalose and glycerol, but not from D-arabinose, L-arabinose, cellobiose, dextrin, D-fructose, D-galactose, D-glucose, inulin, lactose, D-mannose, melezitose, $\alpha$-methyl D-glucoside, $\alpha$-methyl $\mathrm{D}$-mannoside, raffinose, salicin, L-sorbose, sucrose, D-xylose, D-dulcitol, meso-erythritol, myo-inositol, D-mannitol, D-sorbitol or D-xylitol. The predominant cellular fatty acid is ai- $C_{15: 0}$. The DNA $G+C$ content of the type strain is $68.3 \mathrm{~mol} \%$.

The type strain, DSW $-2^{\mathrm{T}} \quad\left(=\mathrm{KCTC} 13436^{\mathrm{T}}=\mathrm{DSM}\right.$ $22126^{\mathrm{T}}$ ), was isolated from a seaweed sample taken on the coast of Mara Island, Jeju, Republic of Korea.

\section{Acknowledgements}

This work was supported by the 21C Frontier Microbial Genomics and Application Center Program, Ministry of Science \& Technology, Republic of Korea.

\section{References}

Alonso-Vega, P., Santamaria, R. I., Martínez-Molina, E. \& Trujillo, M. E. (2008). Promicromonospora kroppenstedtii sp. nov., isolated from sandy soil. Int J Syst Evol Microbiol 58, 1476-1481. 
An, D.-S., Im, W.-T., Yang, H.-C., Kang, M. S., Kim, K. K., Jin, L., Kim, M. K. \& Lee, S.-T. (2005). Cellulomonas terrae sp. nov., a cellulolytic and xylanolytic bacterium isolated from soil. Int J Syst Evol Microbiol 55, 1705-1709.

Bagnara, C., Toci, R., Gaudin, C. \& Belaich, J. P. (1985). Isolation and characterization of a cellulolytic microorganism, Cellulomonas fermentans sp. nov. Int J Syst Bacteriol 35, 502-507.

Brosius, J., Palmer, M. L., Kennedy, P. J. \& Noller, H. F. (1978). Complete nucleotide sequence of $16 \mathrm{~S}$ ribosomal RNA gene from Escherichia coli. Proc Natl Acad Sci U S A 75, 4801-4805.

Brown, J. M., Frazier, R. P., Morey, R. E., Steigerwalt, A. G., Pellegrini, G. J., Daneshvar, M. I., Hollis, D. G. \& McNeil, M. M. (2005). Phenotypic and genetic characterization of clinical isolates of CDC coryneform group A-3: proposal of a new species of Cellulomonas, Cellulomonas denverensis sp. nov. J Clin Microbiol 43, 1732-1737.

Brown, J. M., Steigerwalt, A. G., Morey, R. E., Daneshvar, M. I., Romero, L.-J. \& McNeil, M. M. (2006). Characterization of clinical isolates previously identified as Oerskovia turbata: proposal of Cellulosimicrobium funkei sp. nov. and emended description of the genus Cellulosimicrobium. Int J Syst Evol Microbiol 56, 801-804.

Busse, H.-J., Zlamala, C., Buczolits, S., Lubitz, W., Kämpfer, P. \& Takeuchi, M. (2003). Promicromonospora vindobonensis sp. nov. and Promicromonospora aerolata sp. nov., isolated from the air in the medieval 'Virgilkapelle' in Vienna. Int J Syst Evol Microbiol 53, 15031507.

Elberson, M. A., Malekzadeh, F., Yazdi, M. T., Kameranpour, N., Noori-Daloii, M. R., Matte, M. H., Shahamat, M., Colwell, R. R. \& Sowers, K. R. (2000). Cellulomonas persica sp. nov. and Cellulomonas iranensis sp. nov., mesophilic cellulose-degrading bacteria isolated from forest soils. Int J Syst Evol Microbiol 50, 993-996.

Felsenstein, J. (1981). Evolutionary trees from DNA sequences: a maximum likelihood approach. J Mol Evol 17, 368-376.

Felsenstein, J. (1985). Confidence limits on phylogenies: an approach using the bootstrap. Evolution 39, 783-791.

Felsenstein, J. (1993). PHYLIP (phylogeny inference package), version 3.5c. Distributed by the author. Department of Genome Sciences, University of Washington, Seattle, USA.

Fitch, W. M. (1971). Toward defining the course of evolution: minimum change for a specific tree topology. Syst Zool 20, 406-416.

Groth, I., Schumann, P., Schuetze, B., Augasten, K., Kramer, I. \& Stackebrandt, E. (1999). Beutenbergia cavernae gen. nov., sp. nov., an L-lysine-containing actinomycete isolated from a cave. Int J Syst Bacteriol 49, 1733-1740.

Groth, I., Schumann, P., Schütze, B., Gonzalez, J. M., Laiz, L., SaizJimenez, C. \& Stackebrandt, E. (2005). Isoptericola hypogeus sp. nov., isolated from the Roman catacomb of Domitilla. Int J Syst Evol Microbiol 55, 1715-1719.

Hancock, I. C. (1994). Analysis of cell wall constituents of Grampositive bacteria. In Chemical Methods in Prokaryotic Systematics, pp. 63-84. Edited by M. Goodfellow \& A. G. O’Donnell. Chichester: Wiley.

Hong, S. G., Lee, Y. K., Yim, J. H., Chun, J. \& Lee, H. K. (2008). Sanguibacter antarcticus sp. nov., isolated from Antarctic sea sand. Int J Syst Evol Microbiol 58, 50-52.

Hopwood, D. A., Bibb, M. J., Chater, K. F., Kieser, H. M., Lydiate, D. J., Smith, C. P., Ward, J. M. \& Schrempf, H. (1985). Genetic Manipulation of Streptomyces: a Laboratory Manual. Norwich: John Innes Foundation.

Huang, Y., Dai, X., He, L., Wang, Y.-N., Wang, B.-J., Liu, Z. \& Liu, S.-J. (2005). Sanguibacter marinus sp. nov., isolated from coastal sediment. Int J Syst Evol Microbiol 55, 1755-1758.
Jiang, Y., Wiese, J., Cao, Y.-R., Xu, L.-H., Imhoff, J. F. \& Jiang, C.-L. (2009). Promicromonospora flava sp. nov., isolated from sediment of the Baltic Sea. Int J Syst Evol Microbiol 59, 1599-1602.

Jones, B. E., Grant, W. D., Duckworth, A. W., Schumann, P., Weiss, N. \& Stackebrandt, E. (2005). Cellulomonas bogoriensis sp. nov., an alkaliphilic cellulomonad. Int J Syst Evol Microbiol 55, 1711-1714.

Jukes, T. H. \& Cantor, C. R. (1969). Evolution of protein molecules. In Mammalian Protein Metabolism, vol. 3, pp. 21-132. Edited by H. N. Munro. New York: Academic Press.

Kalakoutskii, L. V., Agre, N. S., Prauser, H. \& Evtushenko, L. I. (1989). Genus Promicromonospora Krasil'nikov, Kalakoutskii and Kirillova 1961a, $107^{\mathrm{AL}}$. In Bergey's Manual of Systematic Bacteriology, vol. 4, pp. 2392-2395. Edited by S. T. Williams, M. E. Sharpe \& J. G. Holt. Baltimore: Williams \& Wilkins.

Kroppenstedt, R. M. (1985). Fatty acid and menaquinone analysis of actinomycetes and related organisms. In Chemical Methods in Bacterial Systematics (Society for Applied Bacteriology Technical Series vol. 20), pp. 173-199. Edited by M. Goodfellow \& D. E. Minnikin. New York: Academic Press.

Lee, S. D. (2007). Labedella gwakjiensis gen. nov., sp. nov., a novel actinomycete of the family Microbacteriaceae. Int J Syst Evol Microbiol 57, 2498-2502.

Lee, D. W. \& Lee, S. D. (2008). Aeromicrobium ponti sp. nov., isolated from seawater. Int J Syst Evol Microbiol 58, 987-991.

Li, W.-J., Zhi, X.-Y. \& Euzéby, J. P. (2008). Proposal of Yaniellaceae fam. nov., Yaniella gen. nov. and Sinobaca gen. nov. as replacements for the illegitimate prokaryotic names Yaniaceae Li et al. 2005, Yania Li et al. 2004, emend Li et al. 2005, and Sinococcus Li et al. 2006, respectively. Int J Syst Evol Microbiol 58, 525-527.

Mesbah, M., Premachandran, U. \& Whitman, W. B. (1989). Precise measurement of the $\mathrm{G}+\mathrm{C}$ content of deoxyribonucleic acid by highperformance liquid chromatography. Int J Syst Bacteriol 39, 159-167.

Minnikin, D. E., Patel, P. V., Alshamaony, L. \& Goodfellow, M. (1975). Polar lipid composition in the classification of Nocardia and related bacteria. Int J Syst Bacteriol 27, 104-117.

Rivas, R., Trujillo, M. E., Mateos, P. F., Martínez-Molina, E. \& Velázquez, E. (2004). Cellulomonas xylanilytica sp. nov., a cellulolytic and xylanolytic bacterium isolated from a decayed elm tree. Int J Syst Evol Microbiol 54, 533-536.

Saddler, G. S., Tavecchia, P., Lociuro, S., Zanol, M., Colombo, L. \& Selva, E. (1991). Analysis of madurose and other actinomycete whole cell sugars by gas chromatography. J Microbiol Methods 14, 185-191.

Saitou, N. \& Nei, M. (1987). The neighbor-joining method: a new method for reconstructing phylogenetic trees. Mol Biol Evol 4, 406425.

Schleifer, K. H. \& Kandler, O. (1972). Peptidoglycan types of bacterial cell walls and their taxonomic implications. Bacteriol Rev 36, 407-477.

Schumann, P., Weiss, N. \& Stackebrandt, E. (2001). Reclassification of Cellulomonas cellulans (Stackebrandt and Keddie 1986) as Cellulosimicrobium cellulans gen. nov., comb. nov. Int J Syst Evol Microbiol 51, 1007-1010.

Stackebrandt, E. \& Schumann, P. (2000). Description of Bogoriellaceae fam. nov., Dermacoccaceae fam. nov., Rarobacteraceae fam. nov. and Sanguibacteraceae fam. nov. and emendation of some families of the suborder Micrococcineae. Int J Syst Evol Microbiol 50, 1279-1285.

Stackebrandt, E., Rainey, F. A. \& Ward-Rainey, N. L. (1997). Proposal for a new hierarchic classification system, Actinobacteria classis nov. Int J Syst Bacteriol 47, 479-491.

Stackebrandt, E., Schumann, P. \& Prauser, H. (2002). The family Cellulomonadaceae. In The Prokaryotes: an Evolving Electronic Resource 
for the Microbiological Community, release 3.0. Edited by M. Dworkin, S. Falkow, E. Rosenberg, K. H. Schleifer \& E. Stackebrandt. New York: Springer.

Stackebrandt, E., Schumann, P. \& Cui, X.-L. (2004). Reclassification of Cellulosimicrobium variabile Bakalidou et al., 2002 as Isoptericola variabilis gen. nov., comb. nov. Int J Syst Evol Microbiol 54, 685-688.

Takahashi, Y., Tanaka, Y., Iwai, Y. \& Omura, S. (1987). Promicromonospora sukumoe sp. nov., a new species of the Actinomycetales. J Gen Appl Microbiol 33, 507-519.

Thompson, J. D., Gibson, T. J., Plewniak, F., Jeanmougin, F. \& Higgins, D. G. (1997). The CLUSTAL_X windows interface: flexible strategies for multiple sequence alignment aided by quality analysis tools. Nucleic Acids Res 25, 4876-4882.

Yi, H., Schumann, P. \& Chun, J. (2007). Demequina aestuarii gen. nov., sp. nov., a novel actinomycete of the suborder Micrococcineae, and reclassification of Cellulomonas fermentans Bagnara et al. 1985 as
Actinotalea fermentans gen. nov., comb. nov. Int J Syst Evol Microbiol 57, 151-156.

Yoon, J.-H., Kang, S.-J., Schumann, P. \& Oh, T.-K. (2007). Cellulosimicrobium terreum sp. nov., isolated from soil. Int J Syst Evol Microbiol 57, 2493-2497.

Zhang, Y.-O., Schumann, P., Li, W.-J., Chen, G.-Z., Tian, X.-P., Stackebrandt, E., Xu, L.-H. \& Jiang, C.-L. (2005). Isoptericola halotolerans sp. nov., a novel actinobacterium isolated from saline soil from Qinghai Province, north-west China. Int J Syst Evol Microbiol 55, 1867-1870.

Zhi, X.-Y., Li, W.-J. \& Stackebrandt, E. (2009). An update of the structure and 16S rRNA gene sequence-based definition of higher ranks of the class Actinobacteria, with the proposal of two new suborders and four new families and emended descriptions of the existing higher taxa. Int J Syst Evol Microbiol 59, 589-608. 